\title{
Characterization of phosphofructokinase II and regulation of fructose 2,6-bisphosphate levels in Trichoderma reesei
}

\author{
JosÉ ABRAHÃo Neto* \\ Department of Biochemistry, Institute of Chemistry, and Department of Biochemical and Pharmaceutical Technology, \\ Pharmaceutical Sciences School, University of São Paulo, Caixa Postal 66355, CEP 05389, São Paulo, Brazil
}

(Received 12 May 1992; revised 20 October 1992; accepted 20 January 1993)

\begin{abstract}
Phosphofructokinase II (PFK II) from Trichoderma reesei was partially purified (247-fold). The calculated $K_{\mathrm{m}}$ values for fructose 6-phosphate and ATP were $0.7 \mathrm{mM}$ and $40 \mu \mathrm{M}$, respectively. Upon incubation in the presence of $\left[\gamma^{-32} \mathrm{P} \mid \mathrm{ATP}\right.$, the enzyme formed a radioactive phosphoprotein with molecular mass of $67 \mathrm{kDa}$ in autoradiography analysis after SDS-PAGE. Upon incubation in the presence of ATP-Mg and the catalytic subunit of cAMPdependent protein kinase, its activity was not modified. The same result was obtained when a cell-free extract of T. reese $i$ was incubated with ATP-Mg and cAMP. 2,4-Dinitrophenol caused a transient rise in cAMP levels in the fungal cell. These results provide evidence that the fructose 2,6-bisphosphate level in $T$. reesei is independent of cAMP concentrations and not related to a cAMP-dependent mechanism, but to the availability of substrate fructose 6-phosphate.
\end{abstract}

\section{Introduction}

Fructose 2,6-bisphosphate (Fru-2,6- $\mathrm{P}_{2}$ ) controls glycolysis and gluconeogenesis by activating fructose 6-phosphate 1-kinase (PFK 1; EC 2.7.1.11) and inhibiting fructose 1,6-bisphosphatase (EC 3.1.3.11). Fru-2,6- $\mathrm{P}_{2}$ plays a central regulatory role in carbohydrate metabolism in eukaryotic organisms. Since its discovery (Van Schaftingen \& Hers, 1980), Fru-2,6- $\mathrm{P}_{2}$ has been found in plants (Larondelle et al., 1986), animals (Van Schaftingen, 1987) and fungi (Van Laere et al., 1983; Vandercammen et al., 1990). An additional regulatory role of Fru-2,6- $\mathrm{P}_{2}$ in regulation of the 'futile cycle' (fructose 6-phosphate/fructose 1,6-bisphosphate cycle) has been proposed (Leite et al., 1988).

Fru-2,6- $\mathrm{P}_{2}$ is formed from ATP and Fru-6-P in a reaction catalysed by 6-phosphofructo-2-kinase (PFK II) (El-Maghrabi et al., 1981; Furuya \& Uyeda, 1981; Hue et al., 1981; Van Schaftingen \& Hers, 1981). The hydrolysis of Fru-2,6- $\mathrm{P}_{2}$ to Fru-6-P and $\mathrm{P}_{\mathrm{i}}$ is catalysed,

*Author for correspondence. Fax 0118153575.

Abbreviations: PFK I, ATP:D-fructose-6-phosphate 1-phosphotransferase; PFK II, ATP:D-fructose-6-phosphate 2-phosphotransferase; Fru-6-P, fructose 6-phosphate; Fru-2,6- $\mathrm{P}_{2}$, fructose 2,6bisphosphate; Glu-6-P, glucose 6-phosphate; DNP, 2,4-dinitrophenol; FBPase II, fructose-2,6-bisphosphatase. in liver and lower eukaryotes, by fructose-2,6bisphosphatase (FBPase II; EC 3.1.3.46). In liver, muscle and higher plants, PFK II and FBPase II are associated in a bifunctional protein (Pilkis et al., 1984; Bazan et al., 1989). In yeast FBPase II and PFK II can be separated (Kretschmer et al., 1987; François et al., 1988).

Phosphorylation of the bifunctional enzyme from liver, by a cAMP-dependent protein kinase, causes PFK II inactivation and FBPase II activation (Van Schaftingen, 1987). In Saccharomyces cerevisiae, on the other hand, cAMP-dependent phosphorylation of PFK II activates the enzyme (François et al., 1984).

The filamentous fungus Trichoderma reesei secretes a very efficient cellulolytic system that has synergistic action on cellulose degradation to glucose (Montenecourt \& Eveleigh, 1979; Béguin, 1990). This system is dependent on substrates that can induce the extracellular enzymes (El-Gogary et al., 1989).

The purpose of this work was to characterize PFK II of $T$. reesei and to investigate the control of its activity in relation to the production of Fru-2,6- $\mathrm{P}_{2}$.

\section{Methods}

Materials. Blue trisacryl was from IBF Biotechnics; dithiothreitol, phenylmethylsulphonyl fluoride (PMSF), catalytic subunit of cyclicAMP-dependent protein kinase, aldolase, triosephosphate isomerase 
and $\alpha$-glycerophosphate dehydrogenase were from Sigma; SDS-PAGE molecular mass standards, Superose-6B, DEAE-Sepharose and BlueSepharose were from Pharmacia LKB Biotechnology. Other chemicals were from Merck and were of analytical grade. PFK II of Saccharomyces cerevisiae (François et al., 1988), potato tuber pyrophosphate:fructose-6-phosphate 1-phosphotransferase (Van Schaftingen et al., 1982b), PFK phosphofructokinase of T. reesei (Leite et al., 1988), [2- $\left.{ }^{32} \mathrm{P}\right]$ Fru-2,6- $\mathrm{P}_{2}$ (Van Schaftingen et al., 1982a) were prepared as described previously.

Inoculum and culture conditions. Cultures of $T$. reesei were maintained on potato dextrose agar slants at $4{ }^{\circ} \mathrm{C}$. Inocula were prepared by harvesting spores from $7 \mathrm{~d}$-old cultures in $0.9 \% \mathrm{NaCl}$ and filtering through glass wool. Culture medium contained $0.08 \%$ glycerol, $0.2 \%$ Bacto-peptone (Difco), $0.21 \%\left(\mathrm{NH}_{4}\right)_{2} \mathrm{SO}_{4}, 0.03 \%$ urea, $0.03 \%$ $\mathrm{MgCl}_{2} .7 \mathrm{H}_{2} \mathrm{O}, 0.03 \% \mathrm{CaCl}_{2}$ and $0.1 \%$ trace metal solution $(0.2 \%$ $\mathrm{CoCl}_{2}, 0 \cdot 5 \% \mathrm{FeSO}_{4} \cdot 7 \mathrm{H}_{2} \mathrm{O}, 0 \cdot 15 \% \mathrm{MnSO}_{4} \cdot \mathrm{H}_{2} \mathrm{O}$ and $0 \cdot 17 \% \mathrm{ZnCl}_{2}$ in $28 \mathrm{~mm}-\mathrm{HCl}$ ) in $100 \mathrm{~mm}$-potassium phosphate buffer (pH 6.0). Cultures from spore inocula (final concentration, $10^{6}$ spores $\mathrm{ml}^{-1}$ ) were incubated on a rotatory shaker for $14 \mathrm{~h}$ to yield a physiologically active inoculum.

Germinated spores $(5 \mathrm{ml})$ were added to the above culture medium containing the appropriate carbon source for study. All cultures were incubated on a rotary shaker $(200$ r.p.m. $)$ at $28^{\circ} \mathrm{C}$.

Determination of enzyme activities. PFK II was assayed by determining the production of Fru-2,6- $\mathrm{P}_{2}$ in a mixture containing $50 \mathrm{~mm}$-HEPES, pH 6.9, $10 \mathrm{~mm}-\mathrm{MgCl}_{2}, 100 \mathrm{~mm}-\mathrm{KCl}, 1 \mathrm{~mm}-\mathrm{DTT}, 1 \mathrm{mg}$ bovine serum albumin $\mathrm{ml}^{-1}, 1 \mathrm{~mm}-\mathrm{P}_{\mathrm{i}}, 5 \mathrm{~mm}-$ Fru-6-P, $17.5 \mathrm{~mm}-\mathrm{Glu}-6-\mathrm{P}$ and $5 \mathrm{~mm}$-ATP. At various times, samples $(0.1 \mathrm{ml})$ were mixed with 1 vol. $0 \cdot 1 \mathrm{M}-\mathrm{NaOH}$, incubated for $10 \mathrm{~min}$ and used for determination of Fru-2,6- $\mathrm{P}_{2}$ (Van Schaftingen et al., 1982b).

PFK I activity was determined by following the rate of NADH oxidation at $340 \mathrm{~nm}$ in a reaction mixture containing $50 \mathrm{mM}$-HEPES, pH 7.6, 10 mm- $\mathrm{NH}_{4} \mathrm{Cl}, 5 \mathrm{~mm}-\mathrm{MgCl}_{2}, 2.5 \mathrm{~mm}-\mathrm{ATP}, 5 \mathrm{~mm}-\mathrm{Fru}-6-\mathrm{P}$, 2 mM-DTT, $0.15 \mathrm{~mm}-\mathrm{NADH}$, aldolase $1.0 \mathrm{IU}$, triosephosphate isomerase $5.0 \mathrm{IU}$ and $\alpha$-glycerophosphate dehydrogenase $0.5 \mathrm{IU}$.

All enzymic assays were performed at $30^{\circ} \mathrm{C}$. One unit is the amount of enzyme that catalyses the conversion of $1 \mu \mathrm{mol}$ substrate in $1 \mathrm{~min}$ under the conditions of the assay.

Measurement of cyclic AMP and DNA. Samples of cultures were collected by filtration and the residue was scraped off and frozen in liquid nitrogen within less than $15 \mathrm{~s}$ after collection of the sample. The frozen pellet was weighed, mixed with $1 \mathrm{ml} 20 \%(\mathrm{v} / \mathrm{v})$ perchloric acid and freeze-thawed four times. The extract was centrifuged $(3000 \mathrm{~g}$ for $2 \mathrm{~min}$ ) and the supernatant divided into two samples. One sample was neutralized ( $2 \mathrm{M}-\mathrm{KOH}$ and $0.5 \mathrm{M}$-triethanolamine) and, after centrifugation, was used for determination of cAMP (kit supplied by Amersham). The other sample was used for determination of DNA as described by Abraham et al. (1972).

Purification of the PFK II of rat liver. Livers were isolated from fed rats killed by concussion and used immediately. The tissue was homogenized for $1 \mathrm{~min}$ in a Waring blender with 3 vols cold $25 \mathrm{~mm}-$ HEPES, pH 7.5, $1 \mathrm{~mm}$-DTT, $1 \mathrm{~mm}-\mathrm{PMSF}, 100 \mathrm{mM}-\mathrm{KCl}$ and $0.25 \mathrm{M}-$ sucrose. The purification was carried out essentially as described by Van Schaftingen \& Hers (1986).

Purification of the PFK II of T. reesei. The cells, cultivated in $1 \%$ $(\mathrm{w} / \mathrm{v})$ glucose, were harvested in the stationary phase $10 \mathrm{~h}$ after glucose exhaustion. Cells $(100 \mathrm{~g})$ were homogenized for five $30 \mathrm{~s}$ periods in a cell homogenizer (Marconi T-120) in $300 \mathrm{ml}$ ice-cold solution containing $20 \mathrm{~mm}$-potassium phosphate, pH 7.5, $1 \mathrm{~mm}$-DTT, $1 \mathrm{mM}$-PMSF, $5 \mathrm{mM}$-EDTA and $0.5 \mathrm{M}-\mathrm{KCl}$. The homogenate was centrifuged for
$10 \mathrm{~min}$ at $35000 \mathrm{~g}$ and filtered through glass wool. The purification was performed as described by François et al. (1988).

Phosphorylation of PFK II of liver and T. reesei. The partially purified enzymes $(20 \mu \mathrm{g})$ were incubated with the catalytic subunit of cAMPdependent protein kinase (20 picomolar units $\mathrm{ml}^{-1} ; 1$ picomolar unit transfers 1 pmol phosphate from $\left[\gamma_{-}{ }^{32} \mathrm{P}\right] \mathrm{ATP}$ to hydrolysed, partially dephosphorylated casein per min at $\mathrm{pH} 6.5$ and $30^{\circ} \mathrm{C}$ ) at $30^{\circ} \mathrm{C}$ in a final volume of $0.1 \mathrm{ml}$ containing $10 \mathrm{mM}$-potassium phosphate, $\mathrm{pH} 7 \cdot 5$, $2 \mathrm{mM}$-ATP and $1 \mathrm{~mm}$-DTT. After incubation for various times, samples were collected and mixed with 10 vols $10 \mathrm{~mm}$-potassium phosphate, $\mathrm{pH} 7 \cdot 5,1 \mathrm{~mm}$-DTT, $5 \mathrm{~mm}$-EDTA and $20 \mathrm{~mm}-\mathrm{NaF}$. The PFK II activity was determined as described above.

Protein determination. The concentration of protein was determined by the method of Bradford (1976) with bovine serum albumin as a standard.

\section{Results}

\section{Purification of PFK II}

In view of the differences in the catalytic and regulatory properties of PFK II in higher and lower eukaryotes, we undertook the simultaneous purification of the enzymes from $T$. reesei, $S$. cerevisiae and rat liver PFK II.

The purification of PFK II of $T$. reesei involved extraction, affinity chromatography on blue trisacryl and gel filtration on Superose-6B. The 247-fold purified PFK II was obtained with a yield of $13 \%$ (Table 1). The elution profile of this purification (Fig. 1) showed differences from previous results obtained with $S$. cerevisiae (François et al., 1988).

The purification procedure for rat liver PFK II resulted in 6500 -fold purified enzyme with a specific activity of $286 \mathrm{mU} \mathrm{mg}^{-1}$ and a recovery of $24 \%$ (Table 2 ).

\section{Effect of the catalytic subunit of cAMP-dependent protein kinase on the activity of purified PFK II of $T$. reesei and rat liver}

Incubation of purified T. reese $\mathrm{PFK}$ II with the catalytic subunit of cAMP-dependent protein kinase caused no change in the enzymic activity, whereas under the same conditions rat liver PFK II was inhibited (Table 3).

\section{Experiment with a cell-free system}

In order to verify a possible phosphorylation by a cellspecific cAMP-dependent protein kinase present in the homogenate, the extract of $T$. reese $i$ was incubated with cAMP and ATP-Mg (François et al., 1984). A portion of extract $(200 \mu \mathrm{l})$ was incubated $\left(30^{\circ} \mathrm{C}\right)$ with $5 \mathrm{~mm}-\mathrm{MgSO}_{4}$, $2 \mathrm{mM}-\mathrm{ATP}$ and $10 \mu \mathrm{M}-\mathrm{cAMP}$, and at various times samples were collected and mixed with 5 vols $10 \mathrm{~mm}-$ potassium phosphate, $\mathrm{pH} 7 \cdot 5,1 \mathrm{~mm}-\mathrm{DTT}, 5 \mathrm{~mm}$-EDTA and $20 \mathrm{~mm}-\mathrm{NaF}$. The PFK II activity was determined in 
Table 1. Purification of PFK II from T. reesei

\begin{tabular}{lcccccc}
\hline \hline $\begin{array}{c}\text { Purification } \\
\text { step }\end{array}$ & $\begin{array}{c}\text { Vol. } \\
(\mathrm{ml})\end{array}$ & $\begin{array}{c}\text { Protein } \\
(\mathrm{mg})\end{array}$ & $\begin{array}{c}\text { Total } \\
\text { activity } \\
(\mathrm{mU})\end{array}$ & $\begin{array}{c}\text { Specific } \\
\text { activity } \\
{\left[\mathrm{mU}(\mathrm{mg} \text { protein })^{-1}\right]}\end{array}$ & $\begin{array}{c}\text { Purification } \\
(\text {-fold })\end{array}$ & $\begin{array}{c}\text { Yield } \\
(\%)\end{array}$ \\
\hline Crude extract & 200 & 800 & 131 & $0 \cdot 164$ & 1 & 100 \\
Blue-trisacryl & 40 & $3 \cdot 5$ & $69 \cdot 5$ & $19 \cdot 9$ & 121 & 53 \\
Superose-6B & 20 & $0 \cdot 42$ & 17 & $40 \cdot 5$ & 247 & 13 \\
\hline \hline
\end{tabular}

Table 2. Purification of PFK II from rat liver

\begin{tabular}{lcccccc}
\hline \hline $\begin{array}{c}\text { Purification } \\
\text { step }\end{array}$ & $\begin{array}{c}\text { Vol. } \\
(\mathrm{ml})\end{array}$ & $\begin{array}{c}\text { Protein } \\
(\mathrm{mg})\end{array}$ & $\begin{array}{c}\text { Total } \\
\text { activity } \\
(\mathrm{mU})\end{array}$ & $\begin{array}{c}\text { Specific } \\
\text { activity } \\
{\left[\mathrm{mU}(\mathrm{mg} \text { protein })^{-1}\right]}\end{array}$ & $\begin{array}{c}\text { Purification } \\
(\text {-fold })\end{array}$ & $\begin{array}{c}\text { Yield } \\
(\%)\end{array}$ \\
\hline Crude extract & 350 & 17000 & 748 & 0.044 & 1 & 100 \\
PEG 22\% & 30 & 5625 & 394 & 0.070 & $1 \cdot 6$ & 53 \\
DEAE-Sepharose & 50 & 85 & 264 & $3 \cdot 1$ & $70 \cdot 4$ & 35 \\
Blue-Sepharose & 20 & 0.63 & 181 & 286 & 6500 & 24 \\
\hline \hline
\end{tabular}
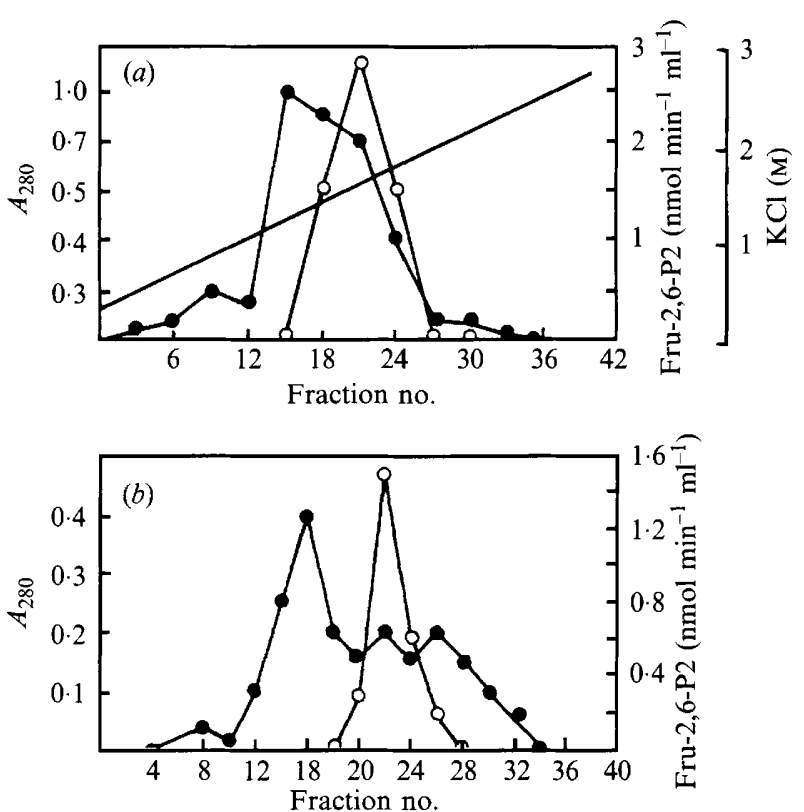

Fig. 1. (a) Elution profile of PFK II of $T$. reesei from the blue-trisacryl column. The crude extract $(200 \mathrm{ml})$ containing $131.2 \mathrm{mU}$ of PFK II was applied to the gel previously equilibrated with $20 \mathrm{mM}$-potassium phosphate, pH 7.5, 1 mM-DTT, 1 mM-PMSF, 5 mM-EDTA and 0.5 M$\mathrm{KCl}$. The column was washed with the same buffer and then eluted with a linear gradient of $\mathrm{KCl}(0.5-3 \mathrm{M}$ in $2 \times 200 \mathrm{ml}$ of same buffer) at a rate of $30 \mathrm{ml} \mathrm{h}^{-1}$. Fractions of $5 \mathrm{ml}$ were collected and PFK II activity was determined as described in Methods. $-A_{280} ; \bigcirc$, Fru-2,6- $\mathrm{P}_{2} ;-$ $\mathrm{KCl}$. (b) Elution profile of PFK II of $T$. reesei from the Superose-6B column. The activity fractions obtained by elution of the column of blue-trisacryl were pooled and concentrated to $2 \mathrm{ml}$ by ultrafiltration on Amicon YM-100 filters. The concentrate was applied to a column of Superose-6B previously washed with 20-mM-HEPES, pH 7.5, 0.3 M$\mathrm{KCl}, 1 \mathrm{mM}$-DTT, 0.4 mM-PMSF and then eluted with the same buffer. Fractions of $5 \mathrm{ml}$ were collected and PFK II activity was determined as described in Methods. $-A_{280} ; \bigcirc$, Fru-2,6- $\mathrm{P}_{2}$.
Table 3. Phosphorylation of PFK II of T. reesei $(A)$ and rat liver $(B)$

The partially purified enzymes $(20 \mu \mathrm{g})$ were incubated at $30^{\circ} \mathrm{C}$ with 20 picomolar units (see Methods) of the catalytic subunit $\mathrm{ml}^{-1}$

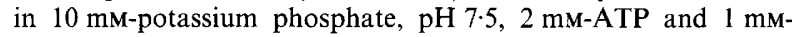
DTT. Samples were collected at the times indicated and mixed with 10 vols $10 \mathrm{~mm}$-potassium phosphate, $\mathrm{pH} 7 \cdot 5,1 \mathrm{~mm}$-DTT, $5 \mathrm{~mm}$-EDTA and $20 \mathrm{~mm}-\mathrm{NaF}$. The PFK II activity was determined as described in Methods

\begin{tabular}{|c|c|c|c|c|}
\hline \multirow{3}{*}{$\begin{array}{l}\text { Time } \\
(\mathrm{min})\end{array}$} & \multicolumn{4}{|c|}{ Fru-2,6- $\mathrm{P}_{2}$ produced $\left[\mathrm{nmol} \mathrm{min}^{-1}(\mathrm{mg} \text { protein })^{-1}\right]$} \\
\hline & \multicolumn{2}{|c|}{ Phosphorylated sample } & \multicolumn{2}{|c|}{ Control } \\
\hline & A & B & A & B \\
\hline 1 & 34 & 250 & 33 & 280 \\
\hline 5 & 33 & 180 & 34 & 280 \\
\hline 10 & 32 & 100 & 33 & 250 \\
\hline 20 & 34 & 100 & 33 & 250 \\
\hline 30 & 33 & 100 & 32 & 250 \\
\hline
\end{tabular}

a mixture containing $50 \mathrm{~mm}$-Tris/acetate, $\mathrm{pH} 7 \cdot 5,1 \mathrm{mg}$ bovine serum albumin $\mathrm{ml}^{-1}, 10 \mathrm{~mm}$-magnesium acetate, 2 mM-P $\mathrm{P}_{\mathrm{i}}, 8 \mathrm{~mm}-$ Glu-6-P, 2 mM-Fru-6-P, $7 \mathrm{~mm}$-ATP and 1 mM-DTT. The Fru-2,6- $\mathrm{P}_{2}$ produced was assayed (Van Schaftingen et al., 1982b). No change in the enzyme activity was detected by this procedure, in good agreement with the results obtained in vitro (see above).

\section{Complexation of PFK II of T. reesei with $\left[\gamma_{-}{ }^{32} P\right] A T P$}

SDS-PAGE analysis of the fractions eluted from the Superose-6B purification of PFK II of $T$. reesei showed the presence of many bands. In order to identify the 


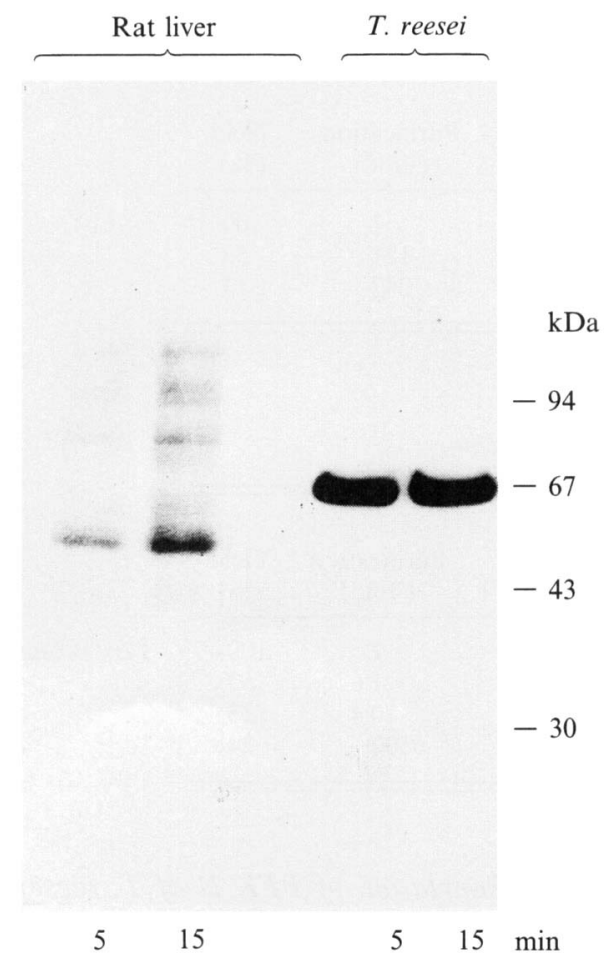

Fig. 2. Complexation of PFK II of rat liver and T. reesei with $\left[\gamma^{-32} \mathrm{P}\right] \mathrm{ATP}$. The partially purified enzymes $(10 \mu \mathrm{g})$ were incubated at $30^{\circ} \mathrm{C}$ with $10 \mu \mathrm{M}-\left[\gamma_{-}{ }^{32} \mathrm{P}\right] \mathrm{ATP}$ (12000 c.p.m. pmol $\left.{ }^{-1}\right)$ in $20 \mathrm{mM}$-HEPES, pH 7.5, 0.1 mM-DTT, $100 \mathrm{mm-KCl,} 0.1 \mathrm{~mm}$-EDTA, $5 \mathrm{~mm}-\mathrm{MgCl}_{2}$. Samples $(10 \mu \mathrm{l})$ were collected at the times indicated, mixed with 1 vol. loading buffer, heated in a boiling water bath for $7 \mathrm{~min}$, and subjected to SDS-PAGE. For autoradiography the gel was dried and exposed at $-80^{\circ} \mathrm{C}$ to $\mathrm{X}$-ray film with an intensifying screen.

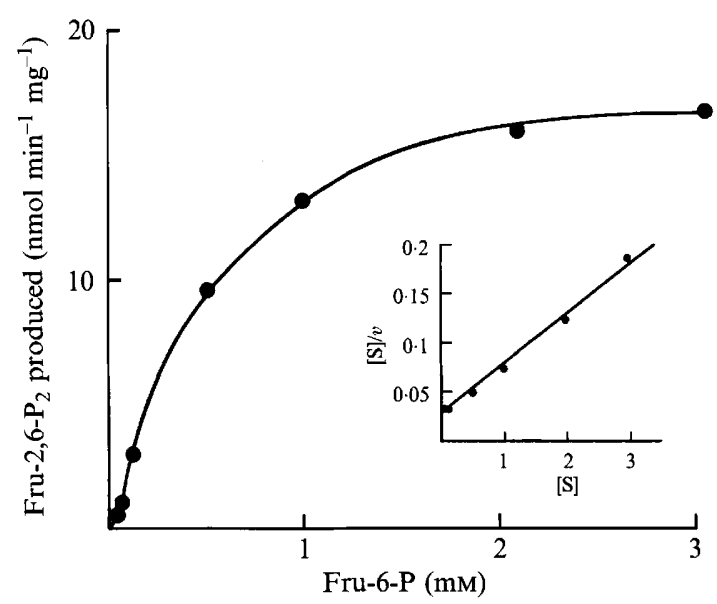

Fig. 3. Saturation curve of PFK II of T. reesei for Fru-6-P. PFK II was assayed in the presence of $50 \mathrm{~mm}$-HEPES, pH $6.9,100 \mathrm{~mm}-\mathrm{KCl}, 5 \mathrm{~mm}-$ $\mathrm{MgCl}_{2}, 1 \mathrm{mM}-\mathrm{DTT}, 1 \mathrm{~mm}-\mathrm{P}_{\mathrm{i}}, 5 \mathrm{~mm}-\mathrm{ATP}$ and $1 \mathrm{mg}$ bovine serum albumin $\mathrm{ml}^{-1}$. The inset shows a plot of [Fru-6-P] $/ v$ against [Fru-6-P].

peptide band corresponding to the subunit of this enzyme, advantage was taken of experimental data suggesting that the mechanism of the (rat liver) PFK II

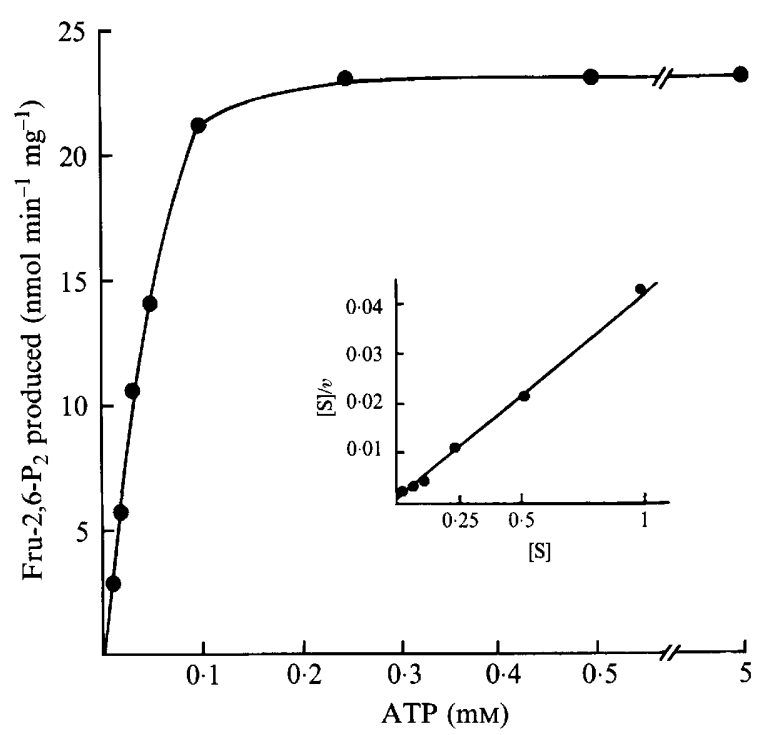

Fig. 4. Saturation curve of PFK II of $T$. reesei for ATP. PFK II was assayed in the presence of $50 \mathrm{~mm}$-HEPES, pH 6.9, $100 \mathrm{mM}-\mathrm{KCl}, 5 \mathrm{mM}-$ $\mathrm{MgCl}_{2}, 1 \mathrm{~mm}-\mathrm{DTT}, 1 \mathrm{~mm}-\mathrm{P}_{\mathrm{i}}, 5 \mathrm{~mm}-\mathrm{Fru}-6-\mathrm{P}$ and $1 \mathrm{mg}$ bovine serum albumin $\mathrm{ml}^{-1}$. The inset shows a plot of [ATP] $/ v$ against [ATP].

catalysis involves the formation of a phosphoryl enzyme intermediate $\left(\mathrm{E}-\mathrm{P}_{\mathrm{i}}\right)$ from ATP and Fru-2,6- $\mathrm{P}_{2}$ (Pilkis et al., 1984). Incubation of purified PFK II of $T$. reesei and rat liver with $10 \mu \mathrm{M}-\left[\gamma-{ }^{32} \mathrm{P}\right] \mathrm{ATP}$ and $2 \mu \mathrm{M}-\left[2-{ }^{32} \mathrm{P}\right]$ Fru2,6- $\mathrm{P}_{2}$ allowed the identification of the protein band corresponding to PFK II of $T$. reesei (Fig. 2).

\section{Kinetic properties of purified PFK II of T. reesei}

The partially purified enzyme displayed typical Michaelis-Menten kinetics, with a $K_{\mathrm{m}}$ of about $0.7 \mathrm{~mm}$ for Fru-6-P (Fig. 3) and $40 \mu \mathrm{M}$ for ATP (Fig. 4).

Stimulation of PFK I of T. reesei by Fru-2,6- $\mathrm{P}_{2}$

The general rule that Fru-2,6- $\mathrm{P}_{2}$ is a positive effector also applies to $T$. reesei PFK I. Addition of Fru-2,6- $\mathrm{P}_{2}$ changed the saturation curve for Fru-6-P from sigmoidal to hyperbolic and decreased the $K_{\mathrm{m}}$ for Fru-6-P (Fig. 5).

Effect of glucose and 2,4-dinitrophenol (DNP) on the concentration of $C A M P$

In order to verify whether addition of glucose and DNP to a suspension of $T$. reese $i$ in stationary phase caused a transient increase in concentration of cAMP, as described previously for the enzymes from $S$. cerevisiae (François et al., 1984) and Neurospora crassa (Ann Dumbrava \& Pall, 1987), the culture of $T$. reesei was 


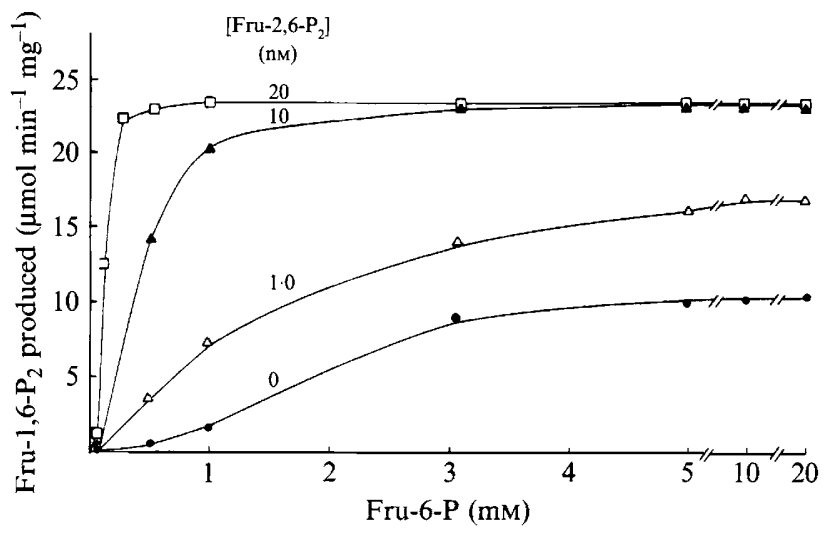

Fig. 5. Effect of Fru-2,6-P ${ }_{2}$ on the saturation curve of T. reesei PFK I for Fru-6-P. PFK I was assayed in the presence of $50 \mathrm{mM}$-HEPES, $\mathrm{pH} 7 \cdot 6, \quad 10 \mathrm{~mm}-\mathrm{NH}_{4} \mathrm{Cl}, 5 \mathrm{~mm}-\mathrm{MgCl}_{2}, 2.5 \mathrm{~mm}-\mathrm{ATP}, 2 \mathrm{~mm}-\mathrm{DTT}$, $0.15 \mathrm{~mm}-\mathrm{NADH}, 1 \mathrm{IU}$ aldolase, $5 \mathrm{IU}$ triosephosphate isomerase, $0.5 \mathrm{IU} \alpha$-glycerophosphate dehydrogenase. The concentrations of Fru-2,6- $\mathrm{P}_{2}$ are shown next to the curves.

Table 4. Effect of addition of glucose and 2,4dinitrophenol (DNP) on the concentration of cAMP

$T$. reesei and $S$. cerevisiae were cultivated under the same conditions as used for purification of PFK II until the homogenization step (see Methods). Glucose was added to the culture of $S$. cerevisiae at a final concentration of $0.1 \mathrm{M}$ and to the culture of $T$. reesei at $0.03 \mathrm{M}$ and $0.1 \mathrm{M}$. DNP was added to the culture of $T$. reesei at a final concentration of $1 \mathrm{~mm}$. At the indicated times, samples of cultures were collected by filtration, frozen in liquid nitrogen and the concentration of cyclic AMP was determined (see Methods).

\begin{tabular}{|c|c|c|c|c|}
\hline \multirow{4}{*}{$\begin{array}{l}\text { Time } \\
(\mathrm{min})\end{array}$} & \multicolumn{4}{|c|}{ cAMP concn $\left[\mathrm{pmol}(\mu \mathrm{g} \mathrm{DNA})^{-1}\right]$} \\
\hline & S. cerevisiae & & T. reesei & \\
\hline & \multirow{2}{*}{$\begin{array}{c}\text { + Glucose } \\
(0 \cdot 1 \mathrm{M})\end{array}$} & \multicolumn{2}{|c|}{+ Glucose } & \multirow{2}{*}{$\begin{array}{l}+\mathrm{DNP} \\
(1 \mathrm{mM})\end{array}$} \\
\hline & & $(0.03 \mathrm{M})$ & $(0 \cdot 1 \mathrm{M})$ & \\
\hline 0 & $3 \cdot 0$ & 0.9 & $0 \cdot 9$ & $0 \cdot 9$ \\
\hline 1 & $3 \cdot 5$ & 0.6 & 0.4 & $1 \cdot 0$ \\
\hline 2 & $9 \cdot 0$ & 0.6 & 0.4 & $3 \cdot 0$ \\
\hline 3 & $4 \cdot 0$ & 0.4 & 0.4 & $2 \cdot 0$ \\
\hline 5 & $4 \cdot 5$ & $0 \cdot 6$ & 0.2 & 1.5 \\
\hline
\end{tabular}

submitted to two concentrations of glucose and to $1 \mathrm{mM}$ DNP. The same procedure was also performed for $S$. cerevisiae in the presence of $0.1 \mathrm{M}$ glucose alone (Table 4 ).

\section{Discussion}

As shown in Tables 1 and 2, the purification of PFK II of rat liver gave a purification factor much greater $(6500-$ fold) than that of the enzyme of $T$. reesei. In order to separate PFK II of $T$. reese $i$ from cAMP-dependent and
cAMP-independent protein kinases, the suggestions of François et al. (1988) were followed. Thus we avoided procedures of purification involving, as a first step, fractionation with polyethylene glycol or chromatography on DEAE-trisacryl or blue-Sepharose which could case the possible activation of PFK II either during the purification or in the assay mixture. This activation, on the other hand, did not occur in the enzyme from liver, either in this work or in others (Van Schaftingen \& Hers, 1986) (Table 2).

$T$. reesei $\mathrm{PFK}$ II was strongly retained on blue trisacryl and eluted only at a high salt concentration. In this respect the behaviour of the $T$. reesei enzyme is comparable to that of the yeast PFK II (François et al., 1988). The elution from blue trisacryl yields a purification of 100 -fold. The active fractions (Fig. 1a) were pooled and concentrated by ultrafiltration and applied to the column of Superose-6B. This step was less efficient in terms of purification; however, it is worth noting that the elution profile of the enzyme was strikingly different from that of the preparation obtained with $S$. cerevisiae (François et al., 1988) (Fig. 1b).

A further, and more fundamental difference between the $T$. reesei enzyme and those of $S$. cerevisiae (François et al., 1984) and rat liver is the lack of cAMP-dependent regulation in the former enzyme (Table 3 ).

Catalysis by rat liver PFK II involves a double displacement with the transient formation of a phosphoryl enzyme intermediate $\left(\mathrm{E}-\mathrm{P}_{\mathrm{i}}\right)$ (Pilkis et al., 1984). Analysis of $\left[{ }^{32} \mathrm{P}\right]$ phosphoprotein formed upon incubation of the purified enzymes with $\left[\gamma_{-}{ }^{32} \mathrm{P}\right] \mathrm{ATP}$ revealed a band with molecular mass of about $55 \mathrm{kDa}$ for liver enzyme (El-Maghrabi et al., 1982; Furuya et al., 1982) and one with a molecular mass of about $67 \mathrm{kDa}$ for the $T$. reesei enzyme (Fig. 2). On the other hand, it was not possible to obtain $\left[{ }^{32} \mathrm{P}\right]$ phosphoprotein upon incubation of $T$. reesei enzyme with $\left[{ }^{32} \mathrm{P}\right] \mathrm{Fru}-2,6-\mathrm{P}_{2}$, indicating that this enzyme is not bifunctional. The purified enzyme (PFK II) of $T$. reesei did not catalyse the phosphorylation of histones, casein and albumin (not shown).

From the saturation curves of PFK II from T. reesei for Fru-6-P and ATP (Figs 3 and 4) $K_{\mathrm{m}}$ values of about $0.7 \mathrm{~mm}$ and $40 \mu \mathrm{M}$, respectively, were obtained. The $K_{\mathrm{m}}$ for Fru-6-P of PFK II from $S$. cerevisiae decreased from $1.3 \mathrm{~mm}$ to $0.6 \mathrm{~mm}$ after phosphorylation (François et al., 1984), values close to those obtained for the $T$. reesei enzyme. On the other hand, the $K_{\mathrm{m}}$ of PFK II from $S$. cerevisiae for ATP $(0.5 \mathrm{~mm})$ is not affected by phosphorylation. Thus the enzyme of $T$. reesei is about tenfold more sensitive for ATP than its counterpart. In addition, the relatively high $K_{\mathrm{m}}$ values for PFK II from $S$. cerevisiae and $T$. reese $i$ indicate that these enzymes are highly dependent on the Fru-6-P concentration. 
The general effect of Fru-2,6- $\mathrm{P}_{2}$ as a potent stimulator of glycolysis also holds for $T$. reesei, since the activity of PFK $I$ in this fungus is greatly increased by this effector (Fig. 5).

The effect of Fru-2,6-P $\mathrm{P}_{2}$ contrasts with that of cAMP in the regulation of carbohydrate metabolism. While Fru-2,6- $\mathrm{P}_{2}$ is known as the most positive effector of PFK $\mathrm{I}$, it acts solely by increasing the glycolytic rate and decreasing gluconeogenesis by inhibition of fructose 1,6-bisphosphatase; cAMP shows a diverse action in eukaryotic cells, that may even be antagonistic. Thus, in liver, cAMP inhibits glycolysis, whereas it has the reverse effect in heart and muscle (François et al., 1988; Kitamura et al., 1989; Pall, 1984; Van Schaftingen \& Hers, 1986; Van Schaftingen, 1987).

François et al. (1984) added DNP to cultures of $S$. cerevisiae and obtained data that suggested a close relationship between levels of Fru-2,6- $\mathrm{P}_{2}$ and a transient rise of cAMP. This relation led to the proposal of a secondary activation of PFK II by a cAMP-dependent phosphorylation. It should be noted, however, that the transient rise of cAMP in lower eukaryotes treated with uncoupler agents, or even with antibiotics which induce pore formation, is a general response and should not be used for establishing specific correlations (Jaynes et al., 1982; Pall et al., 1981; Trevillyan \& Pall, 1979; Uno \& Ishikawa, 1981). For example, the addition of glucose to a suspension of $S$. cerevisiae leads to a transient increase in the concentration of cyclic AMP, but addition to a culture of $T$. reesei, had the opposite effect. Furthermore, the addition of DNP to the $T$. reesei caused a transient rise of cAMP (Table 4) and a twofold increase in Fru2,6- $\mathrm{P}_{2}$ after $30 \mathrm{~min}$ (not shown).

Results shown in this work indicate that, unlike $S$. cerevisiae, levels of Fru-2,6- $\mathrm{P}_{2}$ in $T$. reesei are independent of levels of cAMP, as in Blastocladiella emersonii (Vandercammen et al., 1990). Dictyostelium discoideum (Aragón et al., 1986) and N. crassa (Ann Dumbrava \& Pall, 1987). This may indicate that for these organisms the level of Fru-2,6- $P_{2}$ is controlled by the availability of the Fru-6-P.

I thank Professor Hamza el-Dorry, for having permitted the use of the laboratory where the experiments described in this paper were carried out, and Professor Hernan Chaimovich, for his dedication and attention in kindly helping me to revise this paper. This work was supported by FAPESP. 90/1134.7; 91/3961.0.

\section{References}

Abraham, G. N., Scaletta, C. \& Vaughan, J. H. (1972). Modified diphenylamine reaction for increased sensitivity. Analytical Biochemistry 49, 547-549.

Ann Dumbrava, V. \& Pall, M. L. (1987). Regulation of fructose 2,6bisphosphate levels in Neurospora crassa. Biochimica et Biophysica Acta 925, 210-217.
Aragón, J. J., Sanchez, V. \& Boto, L. (1986). Fructose 2,6bisphosphate in Dictyostelium discoideum. Independence of cyclic AMP production and inhibition of fructose-1,6-bisphosphatase. European Journal of Biochemistry 161, 757-761.

Bazan, J. F., Fletterick, R. J. \& Pilkis, S. J. (1989). Evolution of a bifunctional enzyme; 6-phosphofructo-2-kinase/fructose-2,6bisphosphatase. Proceedings of the National Academy of Sciences of the United States of America 86, 9642-9646.

BÉGUIN, P. (1990). Molecular biology of cellulose degradation. Annual Review of Microbiology 44, 219-248.

BRADFord, M. M. (1976). A rapid and sensitive method for the quantitation of microgram quantities of protein utilizing the principle of protein-dye binding. Analytical Biochemistry 72, 248-254.

El-Gogary, S., Leite, A., Crivellaro, O., Eveleigh, D. \& ElDorRy, H. (1989). Mechanism by which cellulose triggers cellobiohydrolase I gene expression in Trichoderma reesei. Proceedings of the National Academy of Sciences of the United States of America 86, 6138-6141.

El-Maghrabi, M. R., Claus, T. H., Pilkis, J. \& Pilkis, S. J. (1981). Partial purification of a rat liver enzyme that catalyses the formation of fructose 2,6-bisphosphate. Biochemical and Biophysical Research Communications 101, 1071-1077.

El-Maghrabi, M. R., Fox, E., Pilkis, J. \& Pilkis, S. J. (1982). Cyclic AMP-dependent phosphorylation of rat liver 6-phosphofructo 2kinase/fructose 2,6-bisphosphatase. Biochemical and Biophysical Research Communications 106, 794-802.

Francois, J. M., Van Schaftingen, E. \& Hers, H. G. (1984). The mechanism by which glucose increases fructose 2,6-bisphosphate concentration in Saccharomyces cerevisiae. A cyclic AMP-dependent activation of phosphofructokinase 2. European Journal of Biochemistry 145, 187-193.

François, J. M., Van Schaftingen, E. \& Hers, H. G. (1988) Characterization of phosphofructokinase 2 and of enzymes involved in the degradation of fructose 2,6-bisphosphate in yeast. European Journal of Biochemistry 171, 599-608.

FuruYA, E. \& UYEDA, K. (1981). A novel enzyme catalyses the synthesis of activation factor from ATP and D-fructose-6-P. Journal of Biological Chemistry 2556, 7109-7112.

Furuya, E., Yokoyama, M. \& UYEDA, K. (1982). Regulation of fructose-6-phosphate 2-kinase by phosphorylation and dephosphorylation: possible mechanism of coordinated control of glycolysis and glycogenolysis. Proceedings of the National Academy of Sciences of the United States of America 79, 325-329.

Hue, L., Blackmore, P. F. \& Extron, J. H. (1981). Fructose 2,6bisphosphate - hormonal regulation and mechanism of its formation in liver. Journal of Biological Chemistry 256, 8900-8903.

JAYNes, P. K., MCDonough, J. P. \& MAhleR, H. R. (1982). Properties and possible functions of the adenylate cyclase in plasma membranes of Saccharomyces cerevisiae. Molecular and Cellular Biology 2, 1481-1491.

Kitamura, K., Uyeda, K., Kangawa, K. \& Matsuo, K. (1989) Purification and characterization of rat skeletal muscle fructose-6phosphate 2-kinase:fructose-2,6-bisphosphatase. Journal of Biological Chemistry 264, 9799-9806.

Kretschmer, M., Schellenberg, W., Otto, A., Kessler, R. \& HofmanN, E. (1987). Fructose-2,6-bisphosphatase and 6phosphofructo 2-kinase are separable in yeast. Biochemical Journal 246, 755-759.

Larondelle, Y., Mertens, E., Van Schaftingen, E. \& Hers, H. G. (1986). Purification and properties of spinach leaf phosphofructokinase 2/fructose-2,6-bisphosphatase. European Journal of Biochemistry 161, 351-357.

Leite, A., Abrahão Neto, J., Leyton, J. F., Crivelaro, O. \& ElDorRY, H. (1988). Phosphofructokinase from bumblebee flight muscle. Journal of Biological Chemistry 263, 17527-17533.

Montenecourt, B. S. \& Eveleigh, D. E. (1979). Selective screening methods for the isolation of high yielding cellulase mutants of Trichoderma reesei. Advances in Chemistry Series 181, 289-301.

PALL, M. L. (1984). Is there a general paradigm of cyclic AMP action in eukaryotes? Molecular and Cellular Biochemistry 58, 187-191.

Pall, M. L., Trevillyan, J. M. \& Hinman, N. (1981). Deficient cyclic 
adenosine $3^{\prime}, 5^{\prime}$-monophosphate control in mutants of two genes of Neurospora crassa. Molecular and Cellular Biology 1, 1-8.

Pilkis, S. J., Regen, D. M., Stewart, H. B., Pilkis, J., Pate, T. M. \& EL-MaGHRaBI, M. R. (1984). Evidence for two catalytic sites on 6-phosphofructo-2-kinase/fructose 2,6-bisphosphatase. Journal of Biological Chemistry 259, 949-958.

Trevillyan, J. M. \& Pall, M. L. (1979). Control of cyclic adenosine $3^{\prime}, 5^{\prime}$-monophosphate levels by depolarizing agents in fungi. Journal of Bacteriology 138, 397-403.

UNo, I. \& IshikawA, T. (1981). Control of adenosine $3^{\prime}, 5^{\prime}-$ monophosphate level and protein phosphorylation by depolarizing agents in Coprinus macrorhizus. Biochimica et Biophysica Acta 672, $108-113$.

Van Laere, A., Van Schaftingen, E. \& Hers, H. G. (1983). Fructose 2,6-bisphosphate and germination of fungal spores. Proceedings of the National Academy of Sciences of the United States of America $\mathbf{8 0}$, $6601-6605$.

Van Schaftingen, E. (1987). Fructose 2,6-bisphosphate. Advances in Enzymology 59, 315-395.

Van Schaftingen, E. \& Hers, H. G. (1980). Synthesis of a stimulator of phosphofructokinase most likely fructose 2,6-bisphosphate from phosphoric acid and fructose 6-phosphoric acid. Biochemical and Biophysical Research Communications 96, 1524-1531.

Van Schaftingen, E. \& Hers, H. G. (1981). Phosphofructokinase 2 the enzyme that forms fructose 2,6-bisphosphate from fructose 6-phosphate and ATP. Biochemical and Biophysical Research Communications 101, 1078-1084.

Van SChaftingen, E. \& Hers, H. G. (1986). Purification and properties of phosphofructokinase 2 /fructose 2,6-bisphosphatase from chicken liver and from pigeon muscle. European Journal of Biochemistry 159, 359-365.

Van Schaftingen, E., Davies, D. R. \& Hers, H. G. (1982a). Fructose 2,6-bisphosphatase from rat liver. European Journal of Biochemistry $124,143-149$.

Van Schaftingen, E., Lederer, B., Bartrons, R. \& Hers, H. G. $(1982 b)$. A kinetic study of pyrophosphate:fructose 6-phosphate phosphotransferase from potato tubers. European Journal of Biochemistry 129, 191-195.

Vandercammen, A., Françors, J. M., Torres, B. B., Maia, J. C. C. \& Hers, H. G. (1990). Fructose 2,6-bisphosphate and carbohydrate metabolism during the life cycle of the aquatic fungus Blastocladiella emersonii. Journal of General Microbiology 136, 137-146. 